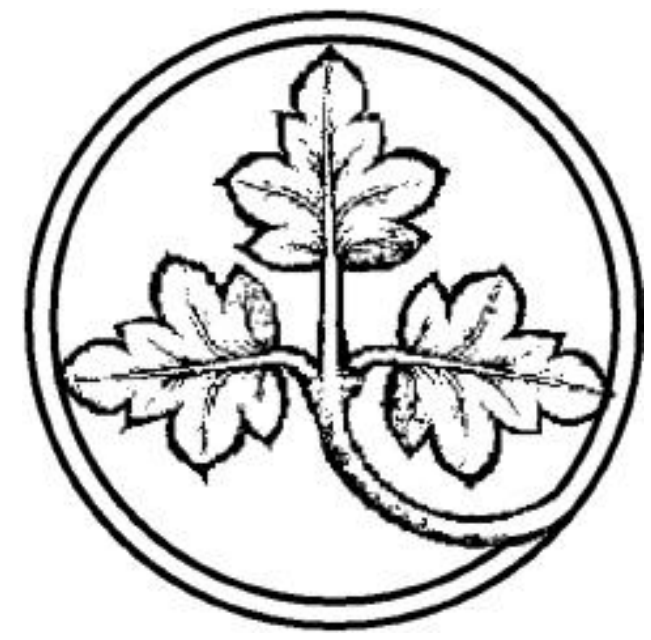

Gemeinschaftsgüter: Recht, Politik und Ökonomie

\author{
Preprints \\ aus der Max-Planck-Projektgruppe \\ Recht der Gemeinschaftsgüter \\ Bonn \\ 2000/7
}

Differential Responses to European Policies:

A Comparison

von

Adriennne Héritier und Christoph Knill 


\section{Differential Responses to European Policies: A Comparison}

What is puzzling about member states' policies is that they respond differently to identical European policy demands and similar external and internal conditions, such as the internationalization of markets, fiscal pressure. While Britain radically liberalized its transport sector, France hesitates to privatize the railroads, while step-by-step deregulating and re-regulating road haulage. The Netherlands apply a mixed strategy of marketliberalization and state intervention in both sectors, Germany proceeds to a significant transformation of both sectors, while Italy produces only very modest reforms in the rail and road haulage sectors. How can the different responses to the same challenges be explicated?

\section{Comparative explanatory scheme}

In seeking to answer the question how, why and to what effect the responses to European policy stimuli vary, we argue that the differences in reform policy output and structural adjustment are a function of three factors: the stage of liberalization prevailing in a country, the dominant belief system or problem solving approach, and the reform capacity of a country. Some influences which are basically the same for all countries studied, such as the influence of world-wide liberalization in both sectors, pronounced fiscal strain in the rail sector, and the necessity of a functioning transport system constituting a central precondition for the working of their economies, are defined as contextual factors.

As regards the first explanatory variable, the specific stage in which a country finds itself with respect to the liberalization of utilities, we distinguish two phases, pre-liberalization and liberalization in which a country found itself when confronted with European policy demands. The stage of preliberalization is defined by the prevailing use of policy instruments which are still clearly of interventionist nature, that is to say, fixing tariffs by administrative decision, using quantitative limits to market access in road haulage, maintaining public ownership of tracks, rolling stock as well service operation, as well as tax funding of infrastructure and service operations in the railways. We claim that depending on which stage a country is in, it will respond differently to European liberalizing demands. For if it is in a stage of pre-liberalization, more will be expected in terms of policy transformation to comply with European policy expectations and domestic actors supporting a reform will be strengthened. If, by contrast, a member state has already 
embarked upon the road of liberalization of transport, less will obviously be required in terms of policy changes. In other words, the stage reflects the degree of congruence with Europe's liberalizing demands; the policy match or mismatch.

However, while being one important factor accounting for a specific response to European liberalization policies, it takes for granted that a reform can take place if there is a mismatch between national and European policies. However, this is not the case. Rather to bring a policy change about, reform capacity is needed. What is reform capacity? We argue that reform capacity is for one thing determined by the number of formal and factual vetopositions which need to be overcome in order to bring a decision about, on the other hand by the politically integrated leadership which can be mustered. As regards the first component, we distinguish between member-states with many formal and factual vetopositions and countries with few formal and factual veto-positions Héritier 2000; Héritier 1997). Many formal veto-positions exist in federalist-decentralized political systems, with multiple-party coalition governments, high ministerial autonomy, an independent constitutional court and an independent central bank; factual veto-positions have to be taken into account where there is a participation of associations in decision-making such as in corporatist sectoral decision-making arrangements. Countries with few formal and factual veto-positions are unitary states with a one-party majority government and administrative decentralization only and no bi- and multi-partite decision making structures.

With respect to the second component of integrated political leadership, it can be provided by formal majoritarian hierarchical government, or by a long-standing and successful practice of consensual bi-, tri- or multi-partitite decision-making incorporating and reconciling divergent interests. Thus, even in the face of multiple formal and factual vetopoints a consensual capacity developed over time in bi- and multipartite decision-making practices may bring such an integration of political and societal forces about. It is, however, also conceivable that a country is characterized by many veto-positions and a simultaneous lack of consensual political leadership. In this case reform capacity will be low.

In analyzing the impact of European policy inputs, it would be wrong to link the number of veto positions and existing types of integrated political leadership in a static or mechanistic way to the likeliness of reform. The relationship is not static and linear as to allow to predict from numerous formal and factual veto-positions and weak integrated political leadership the unlikeliness of reform and vice versa. Rather, we are confronted with a dynamic process. The European policy inputs can be understood as a political resource which may be exploited by some domestic actors in order to improve their relative positions in the domestic political conflicts, and not by others. This may lead to a transformation of the political opportunities in the domestic sectoral arena. Political opportunities are defined at a structural level as the number of available coalition partners and the number of target-points which can be addressed in order to shift the arena of decision-making altogether (such as moving the level of the European Court of Justice) and/or to obtain new policy-parameters for the domestic arena of action (such as by addressing the Commission). By using such new opportunities, the conditions for building the integrated leadership at the national level needed to bring a change a about, are altered. 
The relative importance of individual veto-positions may be diminished, others may increase in weight. In brief, the distribution of power among actors in the domestic arena, which derives from fall-back options in case of non-agreement with other domestic actors, is affected by the entrance of new actors.

Being able to muster reform capacity does not say anything yet about the direction into which this capacity if channelled. While the direction of the influence of European policies is taken as a given, that is pressing for liberalization, the prevailing belief system in a member state (which exists apart from the overall influence of the international liberalization ideology), our second explanatory variable, determines the direction in which reform capacity will materialize. The dominant belief system is defined as the values prevailing as to the role of road and rail transport in this member state. In a country where there are still strong ideological elements of an interventionist or "service public" tradition, the responses to European policy making processed in the domestic political arena will be different from the responses in a country with a very weak interventionist tradition.

On the side of the explanandum we analyze policy outputs, that is legislative changes in the countries under investigation which have come about in the context of European policy making and the structural administrative changes immediately linked with them as well as the changes in structures and patterns of interest intermediation. These changes are qualified as high, medium and low. A high degree of change is defined as a large-scale change of overall problem-solving ideology, that is liberal or interventionist, and an abolishing of all instruments linked with this overall belief system. In the case of road haulage this implies the elimination of quantitative barriers to the market, the administrative setting of tariffs, the use of market-incompatible taxes. In the case of the railroads it means the full privatization of infrastructure, rolling stock and service operations, the full institutional separation of network and services, the opening of full access to the network for train operators, and the end of public subsidies to network and service operators. A medium-range change is defined correspondingly as a mixture of old and new policy elements combining them to about equal parts: in road haulage it may imply a combination of quantitative access restriction with free tariffs or vice versa. In the railways it may be only partial privatization, that is of operations, but not of the network which remains in state ownership, the maintaining of state subsidies and a mere organizational separation of infrastructure and services (or a separation in accounting). A low degree of change accordingly is defined as only a minimal degree of application of market instruments which are introduced in both sectors, while leaving in place the old interventionist measures.

On the basis of the above comparative explanation based on four explanatory factors: contextual influences are held constant. The factor "stage" is held constant by forming two categories of countries within which we compare. In road haulage, one category of countries is in the stage of preliberalization (Germany and Italy) and another category (Netherlands, France and Britain) is in the stage of liberalization when confronted with European policy demands. In the case of rail, all countries are starting to liberalize while being simultaneously faced with European policies. This leaves us with two systematic explanatory variables in both sectors. How did European policies in the two sectors more specifically affect policies and structures in the five countries? 
As revealed by the different case studies contained in this book, the impact of European policy requirements on domestic arrangements varies considerably across countries. The varying impact of European road haulage and railways policies on corresponding regulatory activities and structures at the national level can be understood in light of the distinctive configuration of our explanatory variables given for each country and policy sector under investigation.

\section{$2.1 \quad$ Road Haulage}

In the field of road haulage, the project to establish a liberal transport market throughout the Community made significant progress from the mid-1980s onwards. In this context, the most crucial issue concerning the establishment of a single European transport market was the introduction of cabotage, the operation of non-resident hauliers in foreign domestic markets by corresponding regulations in 1990 and 1993.

It is a crucial characteristic of European road haulage policy that its domestic impact emerges from a restricted "positive" definition of requirements for domestic market policy regulation, and the provision of new strategic opportunities and constraints for domestic actors (Knill/Lehmkuhl 1999). Thus, the liberalisation of cabotage removed the protection of national transport markets, so that states were no longer able to restrict the access of non-resident operators to the domestic market. Apart from these restrictions, however, European legislation allowed for the maintenance of quantitative restrictions and price controls, that is the co-existence of highly regulated domestic markets alongside a deregulated international market, which includes the right to provide domestic transport for non-residents. This way, European policies required only limited instrumental and institutional changes in the domestic regulation of road haulage.

On the other hand, the liberalisation of cabotage confronted domestic markets with international competition, hence affecting the strategic opportunities and constraints of domestic actors and challenging well-established regulatory arrangements. Thus, the introduction of cabotage, which revoked the member states opportunities to protect their markets from foreign competition, created new strategic options for certain actor groups, such as users of transport services (e.g. companies can decide whether they have their goods transported by foreign or domestic hauliers), while reducing the number of feasible options for others (e.g. in light of European competition domestic tariff regimes for road transport are no longer effective to promote the market position of national hauliers). In other words, the European liberalisation of cabotage basically operates through the mechanism of "regulatory competition", putting pressure on the member states to redesign domestic market regulations in order to avoid regulatory burdens restricting the competitiveness of domestic industries.

As revealed by the case studies contained in this book, European road haulage policy triggered highly different patterns of regulatory change in the five countries under 
investigation. While persistence of existing arrangements reflects the dominant scenario in the British case, patterns of change reach from liberalisation in Germany to social reregulation in France, liberalisation and economic stimulation in the Netherlands and increased interventionism in Italy.

At first glance, this variance is highly surprising. As the member states were to a similar extent confronted with new opportunities and constraints implied by European liberalisation activities, one could have expected an overall pattern of converging approaches in domestic market regulation. Moreover, road haulage policy in all countries under study was characterised by and subject to rather similar social, economic and political context conditions. Notwithstanding minor differences in degree, the transport sector is considered to be of high economic importance in all countries under study. The same picture holds true with respect to the overall economic and industrial development, population density, standards of living and social services, liberal-democratic politics with party and interest group participation in policy-making, as well as well-developed administrative systems. As a consequence, the five countries were to a similar extent confronted with potential impacts emerging from the European liberalisation of cabotage.

How can we explain the different domestic responses to EU policy? Which factors account for the fact that new strategic opportunities and constraints implied by European arrangements did not lead to converging regulatory trends at the domestic level, notwithstanding similar European requirements and domestic context conditions? As we have pointed out above, the varying European impact on domestic road haulage policy can be understood in terms of three explanatory factors, namely the stage of liberalisation in which domestic haulage policy was confronted with European legislation, the capacity for sectoral reform as well as the prevailing belief systems of a country with respect to transport regulation.

As summarised in table 1 , the significant differences in domestic regulatory change and persistence in light of pre-existing policies new opportunities and constraints created by European liberalisation are reflected in distinctive configurations of these explanatory factors in each country under study. Before investigating the linkage between variable configuration and domestic adjustment patterns from a comparative perspective, we will elaborate on our classification of cases with respect to these variables. 
Table 1: Explanatory Factors and Policy/Structural Change in Road Haulage Policy

\begin{tabular}{|c|c|c|c|c|c|}
\hline & Germany & Italy & Britain & Netherlands & France \\
\hline $\begin{array}{l}\text { Liberali- } \\
\text { sation Stage }\end{array}$ & $\begin{array}{c}\text { pre- } \\
\text { liberalisation }\end{array}$ & $\begin{array}{c}\text { pre- } \\
\text { liberalisation }\end{array}$ & liberalisation & liberalisation & liberalisation \\
\hline Ideology & interventionist & interventionist & pro-liberal & liberal + state & $\begin{array}{l}\text { contested pro- } \\
\text { liberal / } \\
\text { interventionist }\end{array}$ \\
\hline $\begin{array}{l}\text { Reform } \\
\text { Capacity }\end{array}$ & $\begin{array}{l}\text { medium: } \\
\text { - mult. formal } \\
\text { veto points } \\
\text { - mult. factual } \\
\text { veto points } \\
\text { - weak formal } \\
\text { leadership } \\
\text { - strong } \\
\text { factual } \\
\text { leadership }\end{array}$ & $\begin{array}{l}\text { low: } \\
\text { - mult. formal } \\
\text { veto points } \\
\text { - mult. factual } \\
\text { veto points } \\
\text { - weak formal } \\
\text { and factual } \\
\text { leadership }\end{array}$ & $\begin{array}{l}\text { high } \\
\text { - few formal } \\
\text { veto points } \\
\text { - strong } \\
\text { formal and } \\
\text { factual } \\
\text { leadership }\end{array}$ & $\begin{array}{l}\text { medium: } \\
\text { - few formal } \\
\text { veto points } \\
\text { - mult. factual } \\
\text { veto pointsp } \\
\text { - strong } \\
\text { formal } \\
\text { leadership and } \\
\text { factual } \\
\text { leadership }\end{array}$ & $\begin{array}{l}\text { medium: } \\
\text { - few formal } \\
\text { veto points } \\
\text { - mult. factual } \\
\text { veto points } \\
\text { - strong } \\
\text { formal pol. } \\
\text { leadership }\end{array}$ \\
\hline $\begin{array}{l}\text { Change in } \\
\text { Regulation }\end{array}$ & $\begin{array}{c}\text { high: } \\
\text { liberalisation }\end{array}$ & $\begin{array}{c}\text { low: } \\
\text { increased } \\
\text { intervention }\end{array}$ & $\begin{array}{c}\text { low: } \\
\text { no change }\end{array}$ & $\begin{array}{l}\text { medium: } \\
\text { re-regulation } \\
\text { through } \\
\text { public/private }\end{array}$ & $\begin{array}{l}\text { medium: } \\
\text { social re- } \\
\text { regulation }\end{array}$ \\
\hline $\begin{array}{l}\text { Domestic/ } \\
\text { European } \\
\text { Origin }\end{array}$ & $\begin{array}{l}\text { domestic: + } \\
\text { European: + }\end{array}$ & $\begin{array}{l}\text { domestic: - } \\
\text { European: + }\end{array}$ & $\begin{array}{l}\text { domestic: - } \\
\text { European: - }\end{array}$ & $\begin{array}{l}\text { domestic: + } \\
\text { European: + }\end{array}$ & $\begin{array}{l}\text { domestic: + } \\
\text { European: + }\end{array}$ \\
\hline
\end{tabular}

\section{Domestic Variable Constellations}

With respect to the stage of liberalisation in which domestic haulage policy was exposed to European liberalisation, the five countries can be divided into two groups. The countries of the first group, Germany and Italy, were in the stage of pre-liberalisation, pursuing an interventionist approach of market regulation at the time of European liberalisation. Notwithstanding certain regulatory differences across the two countries, their haulage policies had important characteristics in common: the regulation of market access by quantitative licensing restrictions and the regulation of market operation by a differentiated system of maximum and minimum rate levels. Although the objectives initially associated with the interventionist approach (in particular the protection of railway freight transport and the provision of an efficient transport system) had been achieved neither in Germany nor in Italy, these regulatory failures had implied no fundamental departures from the established approach. 
By contrast, the second group, consisting of Britain, France and the Netherlands, had liberalised domestic market regulation already before corresponding legislation at the European level was enacted. While Britain had liberalised its haulage sector already in 1968, similar reforms took place in France and the Netherlands in the mid 1980s. In view of the failures associated with previous approaches of interventionist regulation, these countries abolished any rate regulations and quantitative restrictions, with market access being solely dependent upon individual qualitative conditions.

Different conditions also exist in terms of the domestic institutional context; i.e., the institutional capacity for sectoral reform. What are the distinctive institutional opportunities and constraints for sectoral actors in order to put through their interests? To what extent are sectoral reform initiatives confronted with formal and factual veto points? In the British case, to begin with, the capacity for sectoral reform can be considered to be very high. On the one hand, this can be traced to general aspects characterising the British political system, which provide the British government with a rather strong position when initiating and putting through political reforms. Opposing actors have limited opportunities to block or reduce the scope and scale of governmental reform proposals, given the low number of institutional veto points in the political decision-making process. On the other hand, the reluctance of the British state to intervene into the haulage sector implied no particular need for a specialised organisation of private interests to demand specific forms of state intervention advantageous to them. In view of the lacking differentiated system of administrative interest intermediation, there exist no particular veto positions emerging from institutionalised exchange relationships between public and private actors, which could reduce the potential for far-reaching reforms within the British haulage sector.

While reform capacity can hence be classified as being very high in Britain, the potential for fundamental sectoral policy changes is at a very low level in the Italian case. From a general perspective, the highly fragmented political-administrative system is characterised by numerous institutional veto factor points which significantly reduce the potential to enact far-reaching reforms. Moreover, the lack of integrated political leadership becomes apparent in Italy's series of short-lived, conflict-ridden multi-party governments. In addition to these general characteristics, the factual veto positions linked with the polarised system of administrative interest intermediation (small versus large haulage companies) reduced the potential for political consensus on regulatory reforms at the sectoral level.

In contrast to the cases of Britain and Italy, which reflect opposite ends of the same spectrum, the capacity for sectoral reform in France, Germany and Netherlands lies somewhat in between these pole ends. In France, the medium level of reform capacity can be traced to the combination of strong political leadership within a unitary state (which comes quite close to the British case) and the adversarial tradition of state-society relations. The potential of the government to realise political reforms is restricted by the high societal capacity for political mobilisation. In the haulage sector, the adversarial tradition becomes apparent in a rather strong social movement, resulting in massive strikes in order to force political reforms.

In Germany and the Netherlands, by contrast, the medium level of sectoral reform capacity can be explained by the ambiguous impact of corporatist arrangements. On the one hand, 
corporatist patterns of interaction between public and private actors as well as the delegation of powers to private associations increase the government's need for bargaining and accommodating various societal interests when formulating and implementing political reforms. The relevance of these corporatist patterns is further enhanced by the emergence of representational monopolies; i.e. the existence of strong peak associations which are able to rely on broad political support of their members and the strong linkages between associations and political parties (Schmitter and Lehmbruch 1979; Dyson 1982). This way, the potential for path-breaking regulatory reforms is significantly reduced. On the other hand, the corporatist mediation of diverse interests allows for considerable adaptational flexibility and ample opportunities to adjust political strategies in light of differing problems, although such adjustments are unlikely to imply radical reforms, given the variety of preferences of the numerous actors involved (Benz and Goetz 1996, 18).

Turning to our third explanatory variable, the dominant belief systems, we find again important differences across the five countries under study. Thus, both British and Dutch road haulage policy are characterised by a liberal ideology which is strongly rooted in the beliefs and ideas of dominant actor coalitions. According to this philosophy, which is often referred to as "Anglo-Saxon tradition" (Button 1993), the achievement of policy goals is left to market forces, with state intervention playing a minor role. In this context, the dominant British ideology, which views market liberalisation and state regulation as mutually exclusive approaches, can be considered as even more 'radical' than the Dutch approach which perceives market liberalisation and parallel state activities to enhance international competitiveness as compatible rather than contradictory concepts.

Germany and Italy, by contrast, were characterised by the dominance of an interventionist ideology. Notwithstanding the fact that this orientation was strongly contested by advocates of a more liberal approach in particular in Germany, the dominant actor coalition in both countries pursued an interventionist concept to transport regulation. Strong economic regulation was expected to deliver an effective and socially desirable transport system by protecting the national railways, smaller haulage companies, and by avoiding negative externalities. Moreover, transport was not seen as a mere service provision (as in the British case), but was linked to other policy objectives in the regional, social, industrial, and environmental field.

While all the countries mentioned so far were characterised by the existence of a dominant - either liberal or interventionist - ideological orientation of how to approach political problems in the road haulage sector, the French case reveals a more ambiguous pattern. Although France had liberalised its road haulage sector during the 1980s, this did not imply a reduced influence of actor coalitions favouring a pro-regulatory approach. Rather the political influence of liberalisers and interventionists can be considered to be well balanced, with no coalition playing a dominating role. This strong contestedness and balance of ideological orientations can be traced to the deeply rooted tradition of state intervention and public service provision by the state, on the one hand, and the increasing reception of neo-liberal ideas within the ministerial bureaucracy on the other hand.

Turning to the scope and direction of regulatory change in national road haulage policy, i.e. our dependent variable, we find again highly varying patterns across the five countries 
under study. Thus, regulatory change remained at a very low level in Britain and Italy. While in Britain neither domestic nor European factors implied the departure from liberal approach to market regulation, the European liberalisation of cabotage had only minor implications on haulage regulation in Italy. In view of the challenges emerging from European liberalisation, Italy gradually increased its interventionist approach in order to protect the domestic market from European competition. A medium level of regulatory change, by contrast, can be observed in France and the Netherlands. In France, both political pressure emerging from the domestic level and European policy activities triggered a development of social re-regulation of the national haulage market, albeit without questioning the dominant liberal approach. A similar mixture of liberalisation and state intervention can be observed in the Netherlands. In the Dutch case, national and European developments led to the emergence of a new approach to domestic haulage regulation, combining a liberalised transport market with an active industrial industrial policy promoting the international competitiveness of the domestic industry through public/private partnerships. In Germany, finally, the abolishment of the highly interventionist regulation in favour of a liberal approach implies a fundamental departure from existing patterns. In this context, the high level of regulatory change in Germany can be traced to the mutual reinforcement of national and Europe-induced reform pressures.

In sum, the classification of the five countries along the three variables accounting for the domestic impact of European road haulage policy reflects a highly differentiated picture. There exists strong variation across countries with respect to all explanatory variables, with each country being characterised by a distinctive variable configuration. Given these differences, the identification of distinctive patterns of regulatory change for each country is hardly surprising. The strong variation in variable configurations, however, does not imply that each variable is of similar importance in order to understand different regulatory developments across countries. As will be shown in the following, it is possible to identify pairs of most similar cases which allow for the reduction of explanatory factors.

\section{Country Comparison}

For this purpose, the five countries under study can be grouped according to the different stage of domestic liberalisation at the time of European liberalisation. While Germany and Italy belong to the group of "pre-liberalisers", Britain, France and the Netherlands had liberalised their domestic haulage markets already before corresponding legislation at the European level was enacted.

These differences in the countries' starting position when being confronted with European liberalisation has to be understood in terms of the distinctive ideological orientations and capacities for regulatory reform given at the domestic level. Thus, all countries had initially pursued a highly interventionist approach to haulage regulation in order to protect railway freight transport and to avoid cut-throat competition within the haulage sector. Moreover, in all countries under study, the strong economic regulation of the haulage market, including quantitative licensing criteria and the definition of maximum and minimum rates, soon turned out to be a major failure with respect to the achievement of the initial objectives. 
Notwithstanding these similar developments and experiences, the corresponding regulatory responses in the five countries reflect a rather different picture. Given the experience of previous regulatory approaches, steps to liberalise the British transport market had already been taken at the end of the 1960s. Rather than being linked to liberal ideas (which entered the general political discourse much later), the British reforms have to be understood in light of the high institutional capacity for regulatory reform. The low number of institutional veto points and the strong capacity for integrated leadership characterising the British political system allowed for a swift regulatory reform in view of the experience with earlier approaches (see the chapter of Christoph Knill).

While Britain reformed its transport policy at a rather early stage, it was only from the mid-1980s onwards that similar developments took place in France and the Netherlands, the two further countries belonging the "liberaliser" group. France and the Netherlands liberalised their domestic haulage markets not only at a later stage, but also introduced the regulatory changes in a more incremental way. These differences in liberalisation pace and timing can be traced to institutional and ideological peculiarities. Anne-Cécile Douillet and Dirk Lehmkuhl show in their chapter that, notwithstanding the powerful position of the French government within a unitary state, both the strong embeddedness of anti-liberal beliefs and the strong societal capacity for political mobilisation posed significant constraints on the French administration in order to put through a more liberal approach to transport policy. As a consequence, liberalisation occurred on the basis of incremental reform steps phased over several years. In the Netherlands, by contrast, the corporatist tradition implied the need for a consensual decision-making process. The abolishment of the interventionist regime was only possible by compensating potential losers. In this context, the liberal orientation characterising the Dutch approach (which - in contrast to Britain - did not impede active state intervention, however) facilitated consensus building within the corporatist structures (see the chapter of Dirk Lehmkuhl).

While the specific constellation of ideological orientations and institutional capacities for regulatory reform given in Britain, France and the Netherlands provided the basis for the liberalisation of domestic haulage markets already before corresponding European measures were enacted, both Germany and Italy were still in the stage of pre-liberalisation at the time of European liberalisation. For the case of Germany, Michael Teutsch shows in his chapter that advocates of liberal reforms were not able to overcome the factual veto position of domestic hauliers benefiting from the existing approach. The corporatist pattern of sectoral regulation was characterised by an interventionist bias, providing the haulage industry with privileged access to the formulation and implementation of German transport policy. For the Italian case, Dieter Kerwer demonstrates that the combination of a highly fragmented political leadership and the factual veto position of the small hauliers had inhibited an attempt to successfully challenge the dominant interventionist approach.

In sum, the different regulatory developments in the five countries under study allows for the distinction of two different stages of liberalisation, in which domestic haulage policy was confronted with European liberalisation activities. As becomes apparent from the comparison of the countries within the same liberalisation stage, the classification of a country as a liberaliser or pre-liberaliser with respect to road haulage policy is not sufficient to understand the varying impact of European legislation at the domestic level. 
This holds true especially when comparing the countries in the pre-liberalisation group, namely Germany and Italy. Thus, the constellation of explanatory variables for both countries reveals a high degree of similarity. Besides a similar liberalisation stage, German and Italian road haulage policy was characterised by an interventionist ideology. In view of this constellation, the strikingly different patterns of regulatory adjustment - liberalisation in Germany versus increased interventionism in Italy - has to be explained by the level of sectoral reform capacity, the only variable where both countries differ.

Dieter Kerwer argues in his piece that - instead of liberalising the domestic market - Italy sought to protect domestic hauliers from the increased competition emerging from a liberalised European market by increasing state intervention. It opted for more rather than less economic regulation, hence increasing the gap between domestic transport policy and European market liberalisation. Instead of introducing widespread regulatory reform, Italy continued its traditionally highly interventionist approach to regulate market access and operation in the domestic haulage market. Moreover, rather than adopting measures to promote the international competitiveness of the sector, Italy attempted to protect domestic hauliers from international competition by offering them specific loans and social tax credits. In view of the persistent pattern of increasing state intervention into the sector, the relationship between public and private actors remained largely unaffected by European legislation. Thus, the association of small hauliers (Unatras) continues to defend its proregulation position by a combination of lobbying and "extortionist" practices. This way, the association exerts a very strong influence on Italian transport policy. By contrast, the association representing the larger enterprises (Coordinamento), which favours a more liberal approach, pursues a less offensive strategy to defend the interests of its members and seeks to co-operate with the administration. However, since the larger companies do not resort to strikes, they are politically less influential than Unatras.

Given the low institutional capacity for sectoral reform in the Italian case, European liberalisation policy implied no sufficient changes in domestic opportunity structures in order to overcome existing institutional veto points. The generally low capacity for integrated political leadership and the highly influential position of actor coalitions in favour of market intervention significantly reduced the opportunities for advocates of liberalisation to trigger domestic reforms. In this context, it was in particular the factual veto position of the small hauliers which inhibited corresponding reforms. As the small hauliers often resort to contortionist practices and call for strikes, in order to press the Ministry of Transport for new tax subsidies and to prevent deregulation, their attempts are usually successful. Given these institutional constraints, the larger hauliers, which are basically in favour of a more liberal regime, were not able to successfully challenge the existing regulatory arrangements, not even with the support and new opportunities provided by European liberalisation policy.

Germany, by contrast, completely abandoned its interventionist regime of market regulation in favour of a liberal approach. The German liberalisation approach becomes apparent in the abolition of restrictive licensing procedures and rate controls which traditionally characterised the system of transport regulation. The regulatory changes are also reflected in changed patterns of administrative interest intermediation. The former arrangements were characterised by a "biased" sectoral corporatism. Actors in favour of 
state intervention, such as haulier associations, were in a privileged position. Decisions were taken jointly by the Transport Ministry and the major haulier associations, while consumer and producer organisations supporting a more liberal approach played a less important role. Haulier associations also played a dominant role in the setting of tariffs as well as the implementation and monitoring of compliance by the federal agency $(B A G)$. With the introduction of a more liberal regime these old institutionalised forms of public/private interaction became less important. As tariffs are now subject to market processes, haulier associations lost their influence in determining transport rates. Moreover, their formal participation of the haulier association in the $B A G$ was abolished. Instead, new informal modes of co-operation between haulier associations and the transport ministry emerged, with the common objective of improving the competitiveness of the German haulage sector. In contrast to the former arrangements, however, these modes of public/private interaction no longer imply a privileged position of haulier associations.

As Michael Teutsch points out in his chapter, the capacity for integrated leadership provided by the corporatist relationship between administration and transport associations facilitated regulatory changes under the impact of European legislation. Although these arrangements were biased in favour of the domestic hauliers, they provided a much weaker veto position against liberal reforms as the position enjoyed by the small hauliers in Italy. Given the well-established patterns of corporatist relationships with the transport administration, contortionist practices and strikes were no feasible option for German hauliers in order to put through their interest. Hence, in contrast to Italy, in the political contest between pro- and anti-liberalisers, the European reform policies played a decisive role. They helped to overcome the de facto veto points by strengthening the position of the liberaliser coalition, that is the opposition of the road hauliers with their vested interests in maintaining market regulation, tipping the scales in favour of the pro-liberalisation party.

The number of explanatory variables can also be reduced when comparing the different patterns of regulatory change in the group of liberalisers, namely Britain, France and the Netherlands. Considering the configuration of variables for France and the Netherlands it becomes apparent that differences in regulatory adjustment (social re-regulation in France versus economic stimulation in the Netherlands) can be traced to differences in dominant belief systems given in both countries.

For the French case, Anne-Cécile Douillet and Dirk Lehmkuhl argue that liberalisation at the European level coincided with a strong tendency towards social re-regulation after liberalizing the domestic haulage market. Re-regulation included not only the strengthening of professional requirements and working time limitations for hauliers, but also the regulation of minimum prices for transport services in order to protect small haulage companies and sub-contractors from cut-throat competition. The introduction of new policy instruments was accompanied by profound changes in patterns of administrative interest intermediation. In response to increasing problems and conflicts emerging from the liberal approach to market regulation, the government set up a corporatist reform Commission, consisting of representatives of the state, haulier associations, and trade unions. These corporatist arrangements not only provided the basis 
for the development of re-regulatory policies, but also contributed to a strengthening of the previously rather weak organisation of trade unions and haulier associations.

As revealed by the French case study, the liberalisation of the domestic haulage sector did not imply the emergence of a dominant ideological orientation in favour of a liberal approach. Rather the strong embeddedness of transport system as a service public provided and regulated by the state implied a constellation of highly contested and equally relevant ideological orientations. In view of an already liberalised domestic market, on the one hand, and the persistence of strong orientations in favour of re-regulation, on the other hand, the - at first glance paradoxical - domestic impact of European liberalisation is to be understood. While the pro-liberalisation coalition had already achieved its basic objectives as a result of domestic market liberalisation prior to European reforms, European liberalisation policy served as an important strategic resource for the re-regulation coalition in order to increase their political influence. By emphasising that European liberalisation might further contribute to the social and political problems already emerging in the liberalised domestic market, European legislation provided an important opportunity for these actors to promote their social re-regulation proposals. In other words: Domestic actors opposing European developments were politically more influential than those actor coalitions supporting European liberalisation policy.

In the Netherlands, Dirk Lehmkuhl observes a quite different approach in order to promote the competitive position of the haulage industry within a liberalised European market. Here where the haulage sector was liberalised already during the 1980s, the role of the state is not restricted to merely safeguarding competition, as it is the case in Britain. Rather the state takes a stimulating role in preparing the industry for future developments by strengthening the social responsibility and self-regulation of economic actors, promoting an innovative and high quality-oriented transport industry. These changes in the regulatory approach had a marked impact on patterns of administrative interest intermediation. While sectoral corporatism remains the basic characteristic of institutionalised interactions between public and private actors, the concrete form of corporatist arrangements underwent significant changes. First, the shift from regulation to stimulation was accompanied by organisational changes within the transport administration and interest associations. Attempts to overcome bureaucratic fragmentation were paralleled by a process of centralisation of organised interests and a restructuring of the road haulage industry. These attempts were financially supported by the government in order to improve the international competitiveness of the Dutch road hauliers. Second, the direction of the meso-corporatist arrangements at the sectoral level underwent significant changes from the former "demand-side" to a "supply-side" corporatism, under which state actors seek to provide a favourable economic framework for economic activities. While the market is seen as the dominant principle of co-ordination, the state insists on defining the overall objectives of this new mode of governance and, in addition to market efficiency, seeks to integrate other goals such as environmental protection.

As opposed to France, the liberalisation of the Dutch transport market coincided with the emergence of a dominant anti-interventionist ideological orientation. Although this does not imply that policy objectives often pursued with state intervention, such as environmental protection, are no longer taken into account, there is an overall consensus 
that self-regulation of economic actors is a better means to achieve these objectives than state intervention. In view of these ideological peculiarities, the strengthening of the competitive position of the haulage industry with an active role played by the state in promoting innovation and self-regulation of economic actors was considered the best way to prepare the industry for the increased competition in European transport markets. In contrast to France, where the persistence of interventionist ideas after liberalisation implied that European liberalisation strengthened actor coalitions in favour of re-regulation, the particular beliefs system given in the Dutch case favoured the adoption of policies of economic stimulation.

Ideological differences also explain the varying regulatory developments in Britain as opposed to France and the Netherlands. Britain is the only country out of the five cases under study where the impact of European road haulage policy can be considered as negligible; i.e. the persistence of regulatory arrangements is the dominant pattern in the British case. Christoph Knill shows in his chapter that EU policy basically confirmed the liberal approach of market regulation, implying only minor adjustments in the setting of policy instruments, but without questioning their basic characteristics. As a consequence, well-established patterns of interaction between public and private actors remained largely unaffected by European developments.

In contrast to the British persistence pattern, the tendency towards social re-regulation in France can be traced to persistent ideological orientations, viewing state intervention as necessary in order to overcome political and social problems emerging from a liberalised domestic market. In Britain such perceptions did not emerge, given the strongly antiinterventionist ideology characterising the country's approach to transport policy. Notwithstanding the high institutional potential for sectoral reform - which was demonstrated by the early liberalisation of the British transport market - European liberalisation implied no departure from existing arrangements for the regulation of the domestic haulage market. In a similar way, the radical liberal philosophy dominant in Britain, which views market co-ordination and state involvement as contradictory activities, inhibited forms of active economic stimulation to be observed in the Dutch case which is characterised by a more pragmatic liberal philosophy to transport regulation.

In sum, the analysis of domestic regulatory adjustment to European liberalisation policy in the road haulage sector reveals highly distinctive patterns of change and persistence in the five countries under study. While persistence of existing arrangements reflects the dominant scenario in the British case, patterns of change reach from liberalisation in Germany to social re-regulation in France, economic stimulation in the Netherlands and increased interventionism in Italy. It is obvious from the strong variance in domestic adjustment patterns, that the new strategic constraints and opportunities created by European policies had a highly diverging impact in different national context constellations. 
For a considerable period of time the European Community had made proposals to liberalize the European railways. However, it was only in the early 1990s that member states supported such attempts at reform at the European level. The reasons are twofold: the Commission changed its approach to railway policy from a detailed legalistic one to a more framework-oriented, voluntaristic one (see Kerwer and Teutsch in this volume; Knill and Lehmkuhl 1999). The loss in market-shares of the railways in intermodal competition deepened the financial crisis of the railways and made the need to act more and more pressing. In 1991 the Council of Transport Ministers agreed on a Directive on the development of the Community's railways demanding the separate accounting of infrastructure and service operations. Third party access is provided for international joint ventures in freight transport and intermodal transport. In view of these rather modest requirements it does not come as a surprise that the member states' responses to the European policy inputs vary to a great extent some - such as Britain - going for radical reforms, while others - such as France - working only incremental changes. Considering the fiscal crisis of the railways and strong intermodal pressure resting upon them, the extent of this differential response to identical pressure and identical - albeit loosely defined - European policy expectations is the puzzle to be solved. In what follows the countries under study are classified along the explanatory variables accounting for the extent, mode and nature of change and the dependent variable reflecting the nature, extent and origin of change.

\section{Domestic Variable Constellations}

In the rail sector the regulatory reforms range from high (Britain) over medium-range (the Netherlands, Germany) to low (France and Italy). Britain and France and Italy represent the opposite ends of the continuum. While Britain has gone for an extensive reform, privatizing the infrastructure and the operation of services, introducing institutional separation, opening the access to the network to competition, however to some extent maintaining state subsidies for infrastructure and services, France has brought about an organizational separation of infrastructure and service operation, has maintained stateownership, but did not open up the access to the network; the same holds for Italy which in principle has decided to introduce an organizational separation as well as intramodal competition in the freight sector, however, does not proceed to implement it. The reforms in the Netherlands and Germany are of a medium range. While the infrastructure is still in state ownership, services are privatized - at least formally in Germany. The networks in both countries at least in theory are accessible for competitors of the incumbents. State subsidies are still granted for infrastructure and the state plays an important role in infrastructure planning. The following variables account for the individual turns which reform has taken in the five countries. 
Table 2: Explanatory Factors and Policy/Structural Change in Railways Policy

\begin{tabular}{|c|c|c|c|c|c|}
\hline & Germany & Italy & Britain & Netherlands & France \\
\hline Ideology & $\begin{array}{l}\text { contested: } \\
\text { interventionist } \\
\text { versus pro- } \\
\text { liberal }\end{array}$ & interventionist & pro-liberal & liberal + state & interventionist \\
\hline $\begin{array}{l}\text { Reform } \\
\text { Capacity }\end{array}$ & $\begin{array}{l}\text { medium: } \\
\text { - mult. formal } \\
\text { veto points } \\
\text { - mult. factual } \\
\text { veto points } \\
\text { - weak formal } \\
\text { leadership } \\
\text { - strong } \\
\text { factual } \\
\text { leadership }\end{array}$ & $\begin{array}{l}\text { low: } \\
\text { - mult. formal } \\
\text { veto points } \\
\text { - mult. factual } \\
\text { veto points } \\
\text { - weak formal } \\
\text { and factual } \\
\text { leadership }\end{array}$ & $\begin{array}{l}\text { high } \\
\text { - few formal } \\
\text { veto points } \\
\text { - strong } \\
\text { formal and } \\
\text { factual } \\
\text { leadership }\end{array}$ & $\begin{array}{l}\text { medium: } \\
\text { - few formal } \\
\text { veto points } \\
\text { - mult. factual } \\
\text { veto pointsp } \\
\text { - strong } \\
\text { formal } \\
\text { leadership and } \\
\text { factual } \\
\text { leadership }\end{array}$ & $\begin{array}{l}\text { medium: } \\
\text { - few formal } \\
\text { veto points } \\
\text { - mult. factual } \\
\text { veto points } \\
\text { - strong } \\
\text { formal pol. } \\
\text { leadership }\end{array}$ \\
\hline $\begin{array}{l}\text { Change in } \\
\text { regulation }\end{array}$ & $\begin{array}{l}\text { medium: } \\
\text { - part. priv. } \\
\text { - inst. sep. } \\
\text { - open access } \\
\text { - interrest } \\
\text { less state } \\
\text { credits }\end{array}$ & $\begin{array}{l}\text { low: } \\
\text { - state owner } \\
\text { - org. separ. } \\
\text { - no open } \\
\text { access } \\
\text { - state subs. }\end{array}$ & $\begin{array}{l}\text { high: } \\
\text { - full priv. } \\
\text { - inst. sep. } \\
\text { - open access } \\
\text { to networks } \\
\text { - state subs. }\end{array}$ & $\begin{array}{l}\text { medium: } \\
\text { - priv. serv. } \\
\text { - inst. sep. } \\
\text { - open access } \\
\text { to networks } \\
\text { - state subs. }\end{array}$ & $\begin{array}{l}\text { low: } \\
\text { - state owner } \\
\text { - org. sep. } \\
\text { - no open } \\
\text { access } \\
\text { - state subs. }\end{array}$ \\
\hline $\begin{array}{l}\text { Domestic/ } \\
\text { European } \\
\text { Origin }\end{array}$ & $\begin{array}{l}\text { domestic: + } \\
\text { European: + }\end{array}$ & $\begin{array}{l}\text { domestic: - } \\
\text { European: + }\end{array}$ & $\begin{array}{l}\text { domestic: + } \\
\text { European: - }\end{array}$ & $\begin{array}{l}\text { domestic: + } \\
\text { European: + }\end{array}$ & $\begin{array}{l}\text { domestic: - } \\
\text { European: + }\end{array}$ \\
\hline
\end{tabular}

The contextual variables, the overall liberalization ideology and fiscal pressure, are the same for all countries under investigation: All member states are subject to the influence of the worldwide liberalization ideology. Since the theory of contested markets had been developed for natural monopolies in public ownership, reform proposals called for a separation of the network infrastructure from the operation of services, at least in accounting, better by means of organizational separation (under the roof of one company), or better still, by establishing separate companies, that is institutional separation. Measures were conceived to increase the managerial autonomy of the railway management from the state, to reduce fiscal dependency of the railways from the state and to introduce intramodal competition, that access to the tracks for competing service operators. Privatization of the newly developed infrastructure and service operation companies were recommended. Similarly, all countries suffered under a fiscal crisis of the railways. All national railways had lost out in intermodal competition, that is their market share in passenger and freight transport had diminished as compared to road haulage and air 
transport. Due to this loss in business and general budget restrictions in all states, the national railway companies came under strong fiscal pressure. In Germany this fiscal crisis was exacerbated by German unification and the ensuing need to incorporate the East German Deutsche Reichsbahn into the Deutsche Bahn AG. Since all countries are similarly subject to these influences, the latter do not explain anything by comparison.

The same holds true for our first explanation variable, the specific stage with respect to liberalization in which a country finds itself when confronted with the European policy requirements. As opposed to the road haulage sector, in the case of the railroads, all of the five countries under study had begun to reform their railways when confronted with the European railway reform. They took first steps of changing public ownership, transforming the state companies into stock companies under private law; they sought to give railway managers more independence from state intervention and attempted to render the financial relations between the state and railways more transparent. None - except Britain - however had introduced intramodal competition for access to the tracks. In view of these more or less extensive reform measures, they all may be positioned in the stage of pre-liberalisation reaching into liberalisation.

Since stage with respect to liberalization is our first truly explanatory variable in comparing the countries is the belief-system prevailing in the sector. Britain adhering to a vigorous neoliberal ideology according to which rail transport can be governed by market principles and serves as an instrument of the economy marks one end of the continuum, while France and Italy postulating that rail transport has to serve the public interest and is characterized by natural monopoly features, hence that the state should continue to play a dominant role in this sector may be placed at its opposite end. The Netherlands and Germany take a middle-range position: the Netherlands have always maintained an ideology according to which market-liberal principles can be reconciled with state interventionism in order to safeguard public interest goals. In Germany the problemsolving philosophy dominating the rail sector - while traditionally service public oriented has more and more come under fire by transport economics calling for the introduction of a contested-market notion for the railways.

Whereas the dominating sectoral belief system marks the direction into which national reforms are likely to develop when changes are being shaped, it cannot offer any insights into the process of change as such. It needs sectoral reform capacity to bring a change about. Regarding this capacity - our second explanatory variable - Britain again with its high reform capacity, based on few formal veto positions and high formal integrated political leadership based on majoritarian, hierarchical one-party government, represents one extreme. Italy is on the other end of the continuum with multiple factual veto-positions and a lack of integrated political leadership due to formal horizontal and vertical fragmentation and short-term duration of governments. The Netherlands, France and Germany are characterized by a medium-range reform capacity. The Netherlands, confronted with multiple de facto sectoral veto positions, can rely on formal majoritarian government, but also on a successful sectoral tradition of consensual corporatist decisionmaking. France is confronted with multiple factual veto positions which can be overcome by formal majoritarian hierarchical government. However, decision-making is embedded in a tradition of adversarial anti-state politics which makes consensus-building difficult. 
Germany, finally, has to overcome win over multiple de facto veto actors in the sector, without - as a federalist state - being able to rely on formal majoritarian hierarchical governmental powers. However, having a long tradition of sectoral corporatist decisionmaking, the necessary consensual capacity for reform can be developed.

As was shown the individual countries are classified very differently along the two explanatory variables "belief systems" and "reform capacity". Each country reveals a distinctive configuration of the two variables and their qualifications. It therefore is not surprising that countries have followed different paths of change in response to the European policy input. Still, as the comparison will show, there are commonalities and differences which offer more general insights.

\section{Explaining the differences}

In spite of the similarity of contextual variables and the similarity of stage of liberalization, the individual countries dealt differently with the policy inputs from Europe. What European legislation requires is contained in Directive 91/440 which prescribes the separation of accounting of infrastructure networks and service operation; tariffs are to be raised such as to over costs and compensation is to be paid for unprofitable services, e.g. the construction, maintenance and operation of unprofitable lines; the long-term objective is to reduce state transfers to precisely the amount of service public obligations. Directive $97 / 118$ and 97/19 provide for the optional introduction of intramodal competition that is competition between different railway companies within and between member states and linked to them - the liberalization of market access to national networks for all international undertakings and combined freight transport.

In analyzing the individual member states' reform policies in the context of the European influence, several combinations of countries to be compared are conceivable, since the constellation of variables in the various member states is highly distinctive: thus, France and Italy are both characterized by an interventionist belief system and multiple factual veto actors, however, differ with respect to formal veto points and the formal preconditions of integrated leadership. Or: Germany and France to a large extent adhere to the same philosophy, and have to face multiple factual veto positions, however, are distinctive as regards formal veto points and the formal basis of integrated leadership. Given this variety of possibilities we settle for categories within which we compare, where most variables may be held constant. Accordingly we distinguish two categories of countries with Germany and Italy with multiple formal and factual veto positions on the one hand, Great Britain, the Netherlands and France with few formal veto-positions on the other.

We look first at the outcomes of the reform and measure them along the four requirements of European legislation, the separation of infrastructure and service operation, managerial autonomy, the fiscal relations between the state and the railways, and intramodal competition; additionally administrative changes linked to the reform and changes in administrative interest intermediation are analyzed. The category of countries, Italy and Germany, with multiple formal and factual veto positions and weak integrated political 
leadership expected to produce modest reforms, indeed reveal only a limited output in Italy, but medium-range one in Germany. As regards organizational reform Italy has taken some steps of formal reorganisation of the railways. The Ferrovie dello stato (FS) is now a holding company consisting of over a hundred separate firms carrying out diverse activities in transport and tourism. However, the separation of infrastructure and service operation has been decided only in principle, but has not been implemented. In Germany, the public monopoly was transformed into a joint stock-company under private law of which the state is the sole stock-owner. The operation of infrastructure was separated from the provision of services at an organizational and accounting level, and different types of transport (longdistance, short distance, freight) were divided as well. The step to institutional separation with completely independent companies has not been taken yet.

With respect to managerial autonomy, in Italy again has decided to enhance in principle the organizational autonomy of the railway management vis-à-vis the state. However, in practical terms these reforms have not amounted to much. Thus, the freedom to set passenger transport tariffs did not increase, rather has remained under political control. And the Italian Parliament, achieved to secure the maintenance or even construction of unprofitable regional lines. In Germany, the granting of interest-free state loans for infrastructure allows for continuing political influence of the federal government. The latter are made dependent upon whether the railways projects are in line with overall infrastructure planning. And more than that, the responsibility of the state for network development has been inserted into the Basic Law.

In regulating the financial relations between the state and the railways, Italy introduced the instrument of contracts define the relationship between the administration and the railways. These contracts, however, are only a very modest move towards increased financial transparency and responsibility. While removing cross-subsidies between infrastructure financing and the operation of services, they do not sanction unprofitability. In addition, as in Italy FS is still dependent on sizeable public subsidies. In Germany, the state maintains a supportive financial role: it took over all debts including obligations for outstanding liabilities for personnel in social security and pensions; and remains financially involved in regional passenger transport and network investment. To increase financial transparency a regime of contracts between regional authorities and service providers was established. In principle, the tracks must be operated according to commercial criteria and cover their full costs. However, if the public authorities require the maintenance of unprofitable lines which serve the public interest they compensate the service providers for these functions.

As to intramodal competition the first step, that is the separation of infrastructure (area rete) and provision of services (area trasporto), has been taken in Italy by introducing an organisational separation under the same holding. However, again implementation is lagging behind. The service division does not yet buy railway capacity from the division managing infrastructure. The second important step, the opening up of the network for access for competing service operators has not been accomplished either. Apart from FS, no railway company has access to the network. Similarly, in Germany, access to tracks has formally been opened to any operator provided that the operator fulfills individual licensing criteria. In practice, however, the Deutsche Bahn AG discriminates against competitors. This is facilitated by the fact that the allocation of slots on the network is 
within the remits of the new railway company. However, a new regulatory body, the Federal Railway Agency watches over possible discrimination of new accessants to the tracks.

The more limited and more extensive reforms of the rail sector in Italy and Germany can to a considerable extent be accounted for on the basis of our two explanatory variables, belief systems and reform capacity. With respect to the first factor it may be said that the prevailing sectoral ideologies in both countries - despite the overall market liberalization ideology - still hold that railways have to serve public service goals. In Germany this belief is particularly pronounced with respect to regional public transport which is reflected in the fact that important public subsidies are maintained in regional transport and the fact that the state still is responsible for infrastructure planning and is the sole stockowner of DBAG. In Italy it is documented in the public ownership of FS, and far-reaching political intervention in management decisions. However, what differs between the two countries with respect to policy ideas, is that in Germany there has been a long tradition of transport economics as a field of research which - starting in the 70s - discussed possibilities of liberalizing natural monopolies. By contrast, no such independent scientific expertise exists in Italy that could be referred to in order to promote a process of reform.

Whereas the direction of reform is defined by the specific mix of existing belief systems and the overall pressure to liberalize in a country, the easiness or cumbersomeness of reform is accounted for by second factor, that is reform capacity as defined by the number of formal and factual veto-positions and the type of integrated political leadership. Both countries are basically characterized by multiple formal and factual veto-positions in rail policy-making. What differs strikingly between the two countries is the capacity of building a reform consensus and a political coalition supporting the latter, as well as the deployment of implementation capacity once decisions have been made. Italian governments are characterized by a fragmented as opposed to an integrated political leadership, at the horizontal and vertical level. Thus the ministry of finance proposed a large-scale reform of the railways along the lines proposed by the European Community, the Prodi Direttiva, without previously consulting the transport ministry. Moreover, Italian governments tend(ed) to be unstable, more conflict-prone and short-lived than German governments, hence the time-horizon of political decision-makers is brief. Except for the Prodi direttiva - which itself came as a surprise to the other ministries - the government has not proposed long-term reform concepts and initiatives regarding railway development, rather left this to other actors, particularly the unions and FS. When partial reform decisions were made on past occasions, such as the decision to come an organizational separation of infrastructure and services, they have not been followed up by implementation.

The railway unions which in the past had put forward reform plans, more recently under the impact of market-liberalization have turned into hard-line opponents of deregulation and privatization. At present they constitute the most important veto-player in whatever reforms are proposed. Thus the Prodi Direttiva met with strong resistance from all railway unions and was quickly brought to a halt. More specifically, the unions objected against the abolition of the unity of the railway organisation and as of 1997 they were still opposed to an organisational reform. They also objected against the attempt to strengthen the financial 
responsibility of the railways because they envisaged that it would lead to cuts in the excessive manpower in the railways which had previously been used by the state as a means to reduce unemployment. Similarly, the endeavours to reclassify the system of professions and wage levels, evoked opposition from the unions. It led to the rise of a new trade union of the train drivers, the Coordinamento macchinisti uniti (COMO) which in turn brought the end of the unity of railway trade unions and made a coordinated decision process among the unions in the reform process even more difficult. The newly founded union, the train drivers, repeatedly used their key functions and called a strike to achieve their goals.

The railway company itself, FS, and the transport ministry constitute two additional important actors which tended to veto each other in their respective reform initiatives: the transport ministry - which does not have a railways division of its own, rather houses staff from the FS in the ministry, depends on the information provided by FS in assessing the efficiency of the railways. Obviously, FS would not provide information testifying to its own inefficiency. At the same time the transport ministry opposed the attempts of FS to gain more autonomy from political intervention in financial management and frequently intervenes in the setting of rail fares. One, railway manager (Necci) of the FS, however, actively developed reform initiatives which were not directed towards a market liberalization, rather advocated European intermodal cooperation in freight transport, while at the same time refusing to introduce intramodal competition as suggested by Community legislation.

In sum, Italian reform capacity is limited by multiple factual veto actors and a lack of horizontal and vertical coordination, which is reflected in a lack of capacity to build supportive coalitions to overcome the resistance of veto-actors, as well as a lack of securing compliance with existing legislation, once a decision has been made. The government did not take the lead in building such a coalition due to horizontal and vertical fragmentation, and unstable governments. The resource Europe was used in a ad-hoc manner by one ministry when proposing the Prodi Direttiva and was not accompanied by an attempt to tie diverse interests together in support of a reform. Therefore it was quickly neutralized.

The German sectoral decision-making system is characterized by a multiplicity of vetopositions as well, however, as opposed to Italy - among the responsible actors there are some, above all the transport ministry and the railway management, who were intensely in favour of a reform and sought to put it on the federal government's political agenda. These actors also successfully mobilized the support of the scientific expertise of transport economics which for quite some time had been advocating a liberalization of the rail sector. Their endeavours were supported by the activities of a high-reputed commission which was instituted to develop a reform proposal and became very influential in building a consensus in the process of reform. An exogenous factor, German unification which exacerbated the hard-pressing fiscal problems, made the need to act even clearer. Also EU legislation and the European railways programme was advocated by the reformers as authoritative in indicating the direction in which rail policies had to develop. 
The expert commission which established an initial consensus regarding the principles which should govern the reform among diverse actors of business, science and politics helped overcome veto-positions. Other important actors - such as the regional states, and the unions, supported by the social democratic party - entered the bargaining process of the reform only later when the central elements of reform had already been defined. However, due their veto positions they still wielded considerable power and shaped the contents of the reform accordingly. Thus the social democrats insisted that interests of the railways' employees be safeguarded and that the power of the state to take influence on infrastructure planning be maintained. This led to the insertion of a clause in the Basic Law which fixes the responsibility of the central government to develop rail infrastructure.

The largest railway union decided to side with the reform for three reasons: they wanted to play a role in the shaping of the reform; and they obtained the concession of the above mentioned guarantee, avoiding all disadvantages with regard to pay-levels, promotion, health care and pensions which could have been linked with a reform. The huge costs of this compensation strategy were taken over by the state. Further, new powers were won. By negotiating directly with the railway management, instead of going through the civil service unions - the railway unions gained in bargaining power and moreover do not depend on ministerial authorization of the negotiated wages any longer. Additionally, under the new rules the staff and the unions appoint half of the railways' supervisory board. The two smaller unions who opposed (one organizing the train drivers) the reform did not win over political key actors - and, as opposed to Italy, - were not able to resort to strike because under German labour law, industrial action is not allowed for political reasons.

In order to realize the reform, another group of important veto actors had to persuaded, the regional governments - which could have blocked the reform in the second chamber representing subnational governments. They obtained important corrections of the reform such as the maintaining of public service goals, the granting of financial transfers to regional and local authorities to enable them to pay for public transport and the maintaining of state responsibility for the building and maintaining of railway infrastructure. Further, the regional states secured competences as regards future structural railways decisions. The consensus was achieved because the federal government was prepared to pay the compensation costs for those who saw themselves as the losers of the reform.

In comparing Italy and Germany it is striking to see that in the German case the capacity to coordinate diverse interests and to compensate potential losers of the reform in exchange for their support is carefully "socially engineered". The support of a newly instituted highly reputed commission and the use of scientific expertise (and of course, the aid of a exogenous event, unification) as well as of Europe is used to push the reform through. In Italy by contrast while there are individual initiatives of reform, they are not incorporated in any coordinative attempts to balance the diverse interests which are involved. Therefore, they failed.

Looking at the outcomes of reform in the second group of countries, that is, Great Britain, the Netherlands and France, we are faced with a far-reaching reform in Britain, a mediumrange reform in the Netherlands and a modest change in France. Britain - as Christoph 
Knill shows in his chapter - has gone furthest with regard to regulatory reform. At the level of organizational reform a radical separation of infrastructure and service operation was carried through which goes beyond what Europe demanded. Railtrack was privatized and has become a private monopoly. It was separated from service operation - which has been taken over by 25 passenger service operating companies - on an institutional basis. An independent private organization was established for rolling stock as well. All these undertaking are linked by a contracts. Passenger and freight operators have to pay for access to the network and lease rolling stock from the rolling stock companies. The Netherlands as is shown by Dirk Lehmkuhl organizational reform has not gone as far. Independent legal units were created to separate private from public tasks: a private, market-oriented component for freight, passenger services, real estate and stations was created; at the same time a government-commissioned public sector was maintained for infrastructure tasks. At the vertical level, transport was regionalized. In France where the reform is the least far-reaching as Anne-Cécile Douillet and Dirk Lehmkuhl show - no step was taken towards privatization, but a separate public entity (RFF) was created for infrastructure, which has taken over a large part of SNCF's debts, owns the infrastructure and is responsible for developing the rail network and the setting of charges for the usage of the rail network. SNCF is in charge of service operation, however, is also responsible for managing and maintaining infrastructure on behalf of RFF. Further, a horizontal division of transport, that is regionalization was introduced: under the monopoly of SNCF, regions are now responsible for local passenger rail transport.

In line with the different scope of reform in the three countries managerial autonomy varies significantly. Direct political intervention into the management of the privately operated track, rolling stock and services companies does not exist in Britain any longer. However, the new private companies are subject to the intensive control of independent regulatory agencies, the Rail Regulator's Office and the Office for Rail Passenger Franchising, now merged into the Strategic Rail Authority. The latter concluded contracts with the service operators setting performance requirements which in turn are controlled by the agency. The fares for services into London are subject to price regulation. In the Netherlands managerial autonomy was introduced to a considerable extent in the commercial sector. Thus the tariff structure is now fixed by Nederlandse Spoorwegen and no longer requires ministerial approval. The public network company - by contrast - is under political instruction to follow specific principles, such as increasing the number of passengers and encouraging a shift of freight transport from road to rail for environmental reasons. In France, state intervention is still dominant, although it has been somewhat reduced through prior reforms. It is reflected in the still dominating policies in favour of the grands projets, that is the "trains à grande vitesse". Public service obligations are still considered to be important. In cosequence, political intervention also prevails in ratesetting in passenger transport, as opposed to the freight sector which is completely free in its decisions. Wage negotiations of SNCF and RFF with unions must be corroborated by government officials, as do employment decisions. As regards infrastructure decisions the government is engaged in long-term planning.

The extent of political intervention is closely related with the nature of the fiscal relations between the state and the private companies in all countries. In Britain, Railtrack and most 
service operators still receive - although decreasingly - public subsidies in order to maintain a minimum service level. In exchange they are subject to the power of the regulatory authorities watching over performance as measured by the criteria defined in the contracts. In the Netherlands the railway company is paid by the government for all politically imposed services which are laid down in specific contracts. The tracks have remained in public ownership, hence they are fully subject to political decisions. In France, the state having taken over part of the debt of SNCF can insist on concessions to be made by SNCF such as regards employment. SNCF is free to borrow on the capital market. To finance the large projects, it has continued to build up debts -though - which subsequently have been transferred to RFF.

As regards intramodal competition, a key feature of the liberalization project - Britain has subjected passenger services to competitive bidding for the operation on individual lines and applies yardstick competition among the different service operators. In freight services their is free access to all lines. Again the reform is less far-reaching in the other two countries. In the Netherlands all charges for the use of infrastructure have been suspended until 2000 so that rail service companies can adjust step by step to the new market situation. By contrast, market competition has been fully introduced in the freight sector. In France there is at present no free access to the network. SNCF is still responsible for all transport operations. However, international groupings and international combined transport enterprises do in principle have access to the French network, however these rights have not been used yet. Still, it is expected that other lines will operate on the French network in the future since RFF will develop an interest in opening up access to the network in order to gain new customers as a source of income. Regionalisation may speed up this process of opening up the market.

The scope and nature of the reforms in the three countries are reflected in corresponding structural administrative changes and transformations of interest intermediation patterns. The British reform completely changed the preexisting administrative structures. Instead of the public monopoly of British Rail a new system of interlocked contracts of private companies was established, which are however subject to newly created regulatory bodies. This will create new patterns of administrative interest intermediation in the dealings between the regulatory bodies and the regulated industry, the shape of which is only beginning to emerge: The two regulatory bodies have been criticized for being being too close to the interests of the rail industry. In the Netherlands the scope of direct administrative action has been reduced in the commercial sector. However, the reform in sticking to the specifically Dutch at arms' length type of steering, did not abolish traditional patterns of interest intermediation, but modified them. In France, by creating RFF and introducing regionalisation, new administrative structures have been created.

How are these differences of a large-scale (GB), medium-range (NL) and modest reform in France to be accounted for? All three countries are characterized by formally integrated political leadership, two of them are confronted with multiple de facto veto positions; yet they deal with them in very different ways. One factor is that the traditional belief systems existing besides the overall liberalization pressure vary strongly in the three countries. 
Britain clearly adheres to an ideology of market liberalization. More specifically, the dominating ideology in Britain is purely neoliberal and pro-market. Under the impact of American deregulation and privatization, put into practical policies by the Thatcher government, this belief-system has permeated almost all of the British public utilities which step by step have been deregulated and privatized. While there is no explicit service public goal in British utilities, the notion of consumer-responsiveness - anchored in the consumer charter - plays an important role and is part of the passenger service operation contracts. In France, by contrast, the prevailing ideology is to view transport as an instrument in a wider social framework which also pursues distributive objectives with high levels of state intervention and a strong notion of service public. The tradition of service public, supported by all political parties and the trade unions, unified opponents during the reform process and effectively limited the scope of the reform. In the case of the Netherlands the dominant ideology has always been a peculiar mixture of marketliberalism and state intervention - which as such are not considered as mutually exclusive, but to be reconciled. These attempts were buttressed by the mobilization of scientific expertise in commissions instituted for the purpose of reform.

The prevailing reform ideas are borne out in the domestic political processes. The reform capacity is constituted by the formal possibilities of integrated political leadership which is however confronted with opposition. In Britain the goals of the far-reaching reform were easily translated into practical policies. This capacity of change is based on integrated political leadership deriving from the fact that there is a majority party in government which is not confronted with formal veto-points. Opponents of the reform, such as the railway unions were split in their view of liberalization and hence were weakened in their political resistance. Labour, the opposition party, although very critical of the reform at the time, was outvoted. The former public monopoly, British Rail, had paradoxically weakened its position as a potential opponent by previously carrying through significant steps of internal organizational reform. What is most interesting in the British case is the fact that - although there was opposition - the government in power did not have to take it into account, rather based on its majority rule could go ahead and push it through in spite of massive criticism. Europe in this context did not play much of a role. It was not needed as a political resource to realize the reform legislation.

The Netherlands are not faced with many formal veto-positions in rail politics, either. Nonetheless, the Dutch tradition of corporatist policy-making implies that factual vetoactors, such as the unions, are taken into account. As it were, the important political actors in the reform process, Nederlandse Spoorwegen, the ministries of economic affairs, of transport and the environment and also the unions (eventually) took a pro-reform stance. The main reason was that urgent action to shift transport to the railways was seen to be needed in order to safeguard the role of Rotterdam and Schiphol as the "gateways to Europe" by avoiding a transport bottleneck on Dutch roads. Hence, reorganisation plans proposed by Nederlandse Spoorwegen met with interest. To objectivize the reform discussion, two committees were established which submitted reform proposals laying the foundation for a general restructuring of the Dutch railways. The actual reform was subsequently shaped in negotiations between Nederlandse Spoorwegen and the Ministry of Transport. Although there was a lot of controversy ("fighting cooperation" Lehmkuhl) 
compromises were struck. Thus a period of transition in licensing access to the networks was allowed for in order to smooth the way into liberalization.

The unions as potential veto players did not oppose the reform in general, but had some reservations regarding organizational separation. However, they supported the reform because they expected in general a strengthening of the railways. In exchange for their political support, they were offered compensations: staff reductions were cushioned by social plans including early retirement plans. The European reform initiative was used in order to accelerate the domestic reform process. The programme of a Common European Railway Policy lent political decision-makers legitimacy to enact their policy ideas.

France too as the other two countries can formally rely on majoritarian integrated political leadership. Quite in contrast to the Netherlands, through adversarial politics has been a pervasive feature of the reform process. Except for the governing party, high civil servants - open vis-à-vis policy initiatives from Brussels - and in part the management of SNCF, the liberalization plans met with opposition. The railway unions protested against the reform of their pension scheme. They also demanded the full maintenance of service public functions and argue that the introduction of market principles into the railways, already subject to stiff intermodal competition, jeopardizes public interest services. Similarly, regionalisation is considered to be a threat to the monopoly of SNCF. In order to underline their protest, they repeatedly organized strikes. In response to the first extensive threeweek strike in 1995 ("les mouvements sociaux de 1995"), the government appointed committees to discuss the problems of the railways. The outcome was the creation of a separate organizational unit for the network, RFF. Under the impression of renewed strikes in 1996 and 1997 and demonstrations in Brussels against the Commission White Paper, the government hesitated with the implementation of 91/440. Similarly, Directives 95/118 and 95/19 on access rights were implemented well past the deadline and further concessions made to the railway unions to the effect that amount of SNCF debt taken over by RFF was increased and the status of railways employees guaranteed. The opposition which had much criticized the 1997 reform - after coming into government - did not abolish RFF.

Interestingly, the pro-reform coalition in France, consisting of the government and in part SNCF management did not use the European legislation in order to reinforce their domestic position in a positive sense. Quite on the contrary, they criticized Brussels for its reform policy and used it in the domestic arena as a "decompression chamber", blaming Brussels and arguing that their own reform plans were not as bad as the plans of Brussels. Opposition to the European Commission's proposals and disconnecting the French reform from the liberal European rail policy, is functional at the domestic level, enhancing chances of support.

In brief, the comparison of Britain, the Netherlands and France shows that while all three can rely on formal preconditions for integrated political leadership, they all faced with multiple factual veto positions. The mode in which the latter are overcome differs largely in the three countries. The British government can rely on formal hierarchical one-party majority government rule; so does France, however, as opposed to Britain it is embedded in an adversarial political culture and has to yield to the pressure from the streets which insist on preserving the values of the old service public culture. The Netherlands could 
exercise integrated political leadership based on formal majoritarian authority, however prefers to rely to a large extent on a tradition of sectoral consensual corporatist decisionmaking which easily reconciles market-liberal values with state intervention.

To what extent may the changes come about in the five countries under study be attributed to European policy requirements? While Europe plays a non-negligible role in some countries (France, the Netherlands, Germany and - to some extent- Italy), it hardly matters in Britain. Here the change originated entirely in a domestic reform process. In all other countries - except France where the nationally initiated changes are minor but may prepare the grounds for further liberalization - the endogenously initiated process of reform went hand in hand with the European reform policy - the second positively supporting the first, such as in Germany and the Netherlands. In France by contrast - scapegoating Europe for "ultra-liberal" reforms was used as a means to pass minimal reforms.

Conclusion: The Differential Impact of Europe

The basic task addressed in this book was to analyse the domestic impact of Europe in two fields of market-making policy, namely road haulage and railways liberalisation. What is the impact of European policies on corresponding policies, administrative structures and patterns of interest intermediation at the national level? How can we explain distinctive patterns of domestic adjustment to European policy requirements?

While it is often claimed that the definition of unique policy requirements at the European level implies converging patterns and structures of domestic regulation, the empirical findings presented in this book suggest a much more differentiated picture. Although there is no doubt that European policy-making leaves its mark on domestic policies, administrative structures and patterns of interest intermediation, the European impact is highly differential across policies and countries. Rather than leading to uniform patterns and structures of domestic policy-making, Europe means different things in different domestic constellations; i.e. the domestic impact of Europe is highly dependent upon the specific policy practice and political constellation given at the national level.

The same European policy might trigger fundamental reforms in one country, while having no consequences at all in some other countries. Depending on the nature of its requirements European legislation might strengthen or weaken the strategic position of different actors in different member states. Moreover, even when affecting the position of similar actors in the same direction, the way these actors adjust to the new opportunities and constraints provided by Europe - due to domestic policy dynamics - may yield highly varying results in terms of domestic patterns of regulatory adjustment. As we have shown above, both the scope and direction of domestic regulatory changes in the context of European policy-making are dependent upon the distinctive constellation of regulatory, ideological and institutional factors at the national level.

There are two reasons which account for the highly distinctive impact of European legislation across policies and countries. The first factor lies in the nature of the European 
policies under investigation. In the case of road haulage, the requirements for domestic adjustment are confined to the restriction of domestic policy options, namely the opportunities to protect domestic markets by restricting market access of non-resident operators. Apart from these restrictions emerging from the liberalisation of cabotage, member states are completely free of how to regulate their domestic haulage markets; i.e. European legislation prescribes no institutional model for domestic adaptation. In contrast to market-correcting policies, such as EU environmental policy, which positively prescribe distinctive regulatory requirements to be complied with at the national level, marketmaking policies, such as road haulage policy, basically exclude certain options from the range of national policy choices (Knill/Lehmkuhl 1999).

In the case of European railways policy, domestic requirements are similarly restricted as a result of the partially broad and open positive prescriptions for domestic compliance. Due to the strong resistance at the member state level towards any Community attempt to intervene into domestic railway policies, the 1991 Directive contains hardly any serious challenges to the well-established railway policies of the member states at the domestic level. The Directive is endowed with a partially non-compulsory nature and a sufficiently ambiguous texture in order to give domestic implementors far-reaching flexibility and discretion in the way in which they comply with its modest requirements. The most demanding requirement of the Directive is that member states shall take the necessary measures to ensure that the accounts for business relating to the provision of infrastructure and those for business relating to the provision of transport activities are kept separate; i.e. the Directive requires only a change in national accounting systems rather than organisational or institutional adaptations (Knill/Lehmkuhl 2000).

In both policies under investigation, the domestic impact of European legislation implies limited substantive and often vague policy inputs which alter institutional opportunities and constraints for domestic actor coalitions, and hence the distribution of power and resources between domestic actors. In this context, changes in domestic opportunity structures refer not only to the provision of domestic actors with new access or exit options from the political process. European policies may also strengthen or weaken the strategic position of domestic actors by providing cognitive resources, such as political legitimacy, policy ideas and solutions to domestic policy problems. In the case of road haulage, for instance, transport users were provided with new exit options, i.e. the opportunity to rely on foreign hauliers, while the opportunities of domestic hauliers to protect their market by access restrictions for non-resident competitors were significantly reduced. In European railways policy, by contrast, domestic opportunity structures were primarily affected by supporting domestic reformers with expertise, political legitimacy and the proposition of European solution to domestic problems, namely the financial crisis of the domestic railways systems.

Against this backdrop the second aspect explaining the highly differential impact of European legislation at the domestic level refers to the strong variance in domestic constellations. European policies had a rather diverging impact on the distinctive institutional opportunities and constraints shaping the strategic interaction of domestic actors. As we have elaborated above, these differences in domestic constellations can be captured by three factors: the specific liberalisation stage (pre-liberalisation versus 
liberalisation) in which a country is confronted with corresponding European policies, the sectoral capacity for regulatory reform (which includes not only the number of institutional veto points, but also the capacity to achieve political consensus), as well as the dominant belief system which affects the direction of potential domestic reforms.

The comparative analysis of differential domestic responses to European policies allows for the distinction of three ideal type patterns of European influence. Depending on the pre-existing policies distinctive regulatory, institutional and ideological constellation at the national level, the domestic impact of European policies can be characterised as

- "positive" resource, strengthening the strategic position of domestic actor coalitions which promote domestic reforms in line with European policy objectives

- "negative" resource, strengthening the strategic position of domestic actor coalitions which oppose European policy objectives and promote a distinctive domestic approach

- neutral, implying no particular changes with respect to the strategic opportunities and constraints of domestic actors

The first pattern, with European policies serving as a positive resource for domestic reformers can be observed in particular in Germany and the Netherlands. In both countries, European policies reinforced domestic reforms which were concurrent with European policy objectives. The most striking case in this respect refers to the impact of European haulage liberalisation in Germany, where European requirements served as an important resource in order to overcome the veto position of actor coalitions in favour of the existing interventionist approach. European constraints on domestic veto players also had an important impact in strengthening the position of the reformers in the case of the German railways privatisation. Thus, the fact that the reform model of the federal government was provided with the 'aura' of the future European railway policies significantly constrained the room of resistance for potential opponents of the reform. Given the foreseeable developments, the question for potential veto players, especially the Länder, the opposition in parliament and the railway union, was not how to block the general developments but how best to influence the shape of the reform which almost inevitably would develop into a new direction (see the chapter of Teutsch in this book; Knill/Lehmkuhl 2000). In the Netherlands, emerging European legislation as well as ideas, concepts and models present in the European sphere played an important role in shaping domestic haulage and railways policies. Domestic reformers used Europe as a resource to advance their economic and political interests, while developing domestic policies compatible with European objectives.

While European influence strengthened and amplified domestic regulatory reforms which were concurrent with European policy objectives in Germany and the Netherlands, the French case reveals an inverse pattern characterising the domestic impact of Europe. With respect to the developments in both haulage and railways policy, European influence paradoxically strengthened the strategic position of those actor promoting reform proposals which were divergent from or even in opposition with European policy objectives. In the case of road haulage where France had already liberalized, European liberalisation strengthened the political influence of actors in favour of re-regulation rather than the pro- 
liberalisation coalition. In other words: Domestic actors were able to increase their political influence by arguing against European reforms. A similar pattern is to be observed in the case of the railways. Rather than using concurrent European policies as a resource to promote the national railways reform in view of the prevailing interventionist tradition, the pro-liberalisation coalition (consisting of the government and parts of the railways management) strove to disconnect their proposals from European initiatives in order to strengthen their position at the national level. By opposing European reforms they sought to win political support for a limited reform, hence using Europe as a "decompression chamber".

The third pattern of a rather neutral impact of European policies on domestic opportunity structures becomes apparent when considering the influence of European policies on British road haulage and railways policy. While in the other countries under study, domestic policies in these areas can no longer be explained without any reference to European developments, there is little connection and interdependence of national and European developments in the case of Britain. In both road haulage and rail, fundamental domestic reforms took place which, albeit concurrent with European policies, were the result of separate, purely national developments.

In contrast to the four countries considered so far, the developments in Italy can hardly be linked to an ideal type pattern of European influence. Rather the impact of European policy in both road haulage and rail suggests a hybrid picture, including all of the three patterns distinguished above. In view of the highly fragmented political system, weak political leadership and short-time horizons as a result of frequent government changes as well as poor implementation, domestic actors tend to rely on ad hoc strategies rather than consistent and long-term concepts in order advance their interests. Neither in the road haulage nor in the railways case Italy developed a clear and consistent approach of how to respond to sectoral problems in the context of European policy-making. Hence, the concrete way, European legislation was used as a resource in the political process is highly dependent on the particular, but highly volatile strategic constellation. In the absence of clear domestic ideas and concepts, domestic actors were hardly capable of using Europe as a consequential, either positive or negative resource. Moreover, as revealed by the attempts to reform the railways during the $1980 \mathrm{~s}$, domestic reform initiatives also emerged completely independent from European developments.

Regardless of the different patterns of European influence to be observed in the five countries under study, it has to be emphasised that in none of our cases European policies can be considered the single and decisive factor bringing about domestic regulatory change. This is particularly obvious in the case of Britain, where domestic reforms occurred independent from European influence. However, it holds also true for the other member states, where we observe a complex picture of European policies reinforcing or weakening reform developments originating from within the domestic context (Héritier forthcoming). The national impact of Europe becomes apparent in amplifying and modifying ongoing domestic reforms. The direction and scope of European influence is dependent upon domestic developments rather than constituting an independent source of domestic change. 
In this context, our country studies suggest that the extent to which Europe makes a difference for national policy-making - given a need to adjust - is more pronounced in countries where the sectoral reform capacity can be characterised as medium, as it is the case in France, Germany and the Netherlands. Notwithstanding important national differences (see above), the medium level of sectoral reform capacity emerges from a rather balanced relationship between considerable formal or factual institutional veto points and integrated leadership capacities. In view of such constellations, where successful reforms generally imply considerable effort in consensus-building, there is a high potential that the impact of European policies on domestic opportunity structures makes an important difference for the national reform capacity. The European impact on domestic actors' veto positions as well as exit and access options to the political process may play a decisive role in facilitating national reforms which might otherwise not have occurred.

This scenario is particularly pronounced in the German haulage reform. Michael Teutsch shows in his analysis that European influence was crucial in tipping the scale in favour of the liberaliser coalition. It can also be observed, however, in the German railways reform, where European legislation reinforced domestic reform attempts. The same holds true for the two other countries characterised by a medium level of sectoral reform capacity, namely France and the Netherlands. In the French road haulage case, Europe provided an important stimulus for domestic re-regulation activities which otherwise might not have occurred in that far-reaching way. Moreover, as pointed out above, Europe served as an important resource to promote and legitimise the albeit limited domestic railways reform (see the chapter of Douillet and Lehmkuhl). As shown by Dirk Lehmkuhl in his chapter, European road haulage and railways policy also significantly strengthened the potential for integrated leadership in the Dutch case.

By contrast, the case studies of Christoph Knill on Britain and Dieter Kerwer on Italy reveal that the impact of Europe hardly makes a difference in countries where the sectoral capacity for regulatory reform is at a very high or very low level. As Christoph Knill demonstrates in his chapter on Britain, new opportunities and constraints emanating from European policies are of minor relevance within a domestic institutional constellation characterised by a low number of veto points and, correspondingly, a very high capacity for integrated leadership. In view of the "luxury" position of political leaders to put through fundamental reforms against strong opposition, integrated leadership does not depend on the support of Brussels. In a similar way, the use of Europe as a resource by opposing actors in order to block governmental reform activities would hardly reflect a substitute for the lack of institutional veto position. In short, Europe makes no difference for existing domestic opportunities to enact or block fundamental regulatory changes.

As illustrated by Dieter Kerwer's chapter, the same statement holds true for the case of Italy, albeit for inverse reasons. In view of numerous institutional veto points and the absence of integrated leadership capacities, the domestic impact of Europe can be considered as being too weak in order to improve the low capacity for sectoral reform. Both in haulage and railways policy the European impact on national opportunity structures was not sufficient to overcome existing institutional veto points. Pressure from Brussels hardly serves as a substitute for missing leadership capacities at the national level. 
The general validity of this linkage between the domestic impact of Europe and national reform capacities seems to depend on several conditions which were fulfilled for our cases under study. First, European reform objectives and national reform initiatives must - at least at a very general level - point into compatible or similar directions, such as, for instance, the privatization, deregulation and liberalization, which reflect common focal points of both European and domestic policy objectives in our cases. Thus, the European influence on British transport policy could have been expected to be much higher, if national and European policies were characterized by contradictory objectives.

Second, European policy requirements must leave broad leeway for domestic adjustment. In other words, the similarity of domestic responses and hence the similarity of European influence can - regardless of differences in national reform capacities - be expected to increase with the extent to which European policies prescribe detailed requirements for domestic compliance, as it can be observed in the environmental field, for instance. Notwithstanding the fact that some member states might implement European policies more effectively than others, the detailed and uniform prescriptions inherent to such policies define very concrete requirements for domestic adjustment which can hardly be ignored in the long run, neither in countries with very high nor very low reform capacities.

Finally, variance in domestic reform capacities are expected to make less difference with respect to the domestic impact of Europe in cases of history-making, constitutional reforms, such as the European Monetary Union, for instance. Given the high political importance and visibility associated with such reforms, there is much higher potential that even in countries with low reform capacities sufficient leadership capacities will be mobilized in order achieve a consensus on corresponding domestic adjustments. 